\title{
PROSEDUR PELAKSANAAN KREDIT USAHA RAKYAT PADA BANK NAGARI CABANG LUBUK GADANG.
}

\author{
Peni Oktaria, Jhon Fernos \\ Akademi Keuangan Perbankan "Pembangunan" Padang \\ : Jhonfernos@akbpstie.ac.id
}

\begin{abstract}
He process of granting KUR at Bank Nagari Lubuk Gadang Branch is carried out in several stages, namely: the stage of credit application, the stage of credit review, the inspection phase (credit analysis), the decision-making stage, and the loan disbursement stage. Prospective debtors who want to get a credit facility first submit a written application and complete the requirements determined by the bank, namely: photocopy of valid identity card (KTP / SIM), photo of the debtor (husband / wife), copy of collateral ownership (STNK) and BPKB), photocopy of business licensing in accordance with applicable regulations. In order for each loan to be granted to the debtor to run in accordance with the terms of the credit agreement, it is necessary to apply credit control to the debtor or in the organizational structure of the company, so that the complete management tools and functions of the company are needed. problematic.
\end{abstract}

Keywords : Store Atmosphere, Location, Consumer Buying Interest

\section{PENDAHULUAN}

Bank sebagai lembaga keuangan yang paling penting perannya dalam masyarakat. Dalam menjalankan perannya maka bank bertindak sebagai salah satu bentuk keuangan yang bertujuan memberikan kredit dan jasa-jasa lainnya. Adapun pemberian kredit itu dilakukan baik dengan modal sendiri, atau dengan dana-dana yang dipercayakan oleh bank pada pihak ketiga maupun dengan jalan mengedarkan alat-alat pembayaran beru berupa uang giral.

Pasal 1 undang-undang nomor 10 tahun 1998 tentang perubahan atas undangundang nomor 7 tahun 1992 tentang perbankan menyebutkan bahwa: bank adalah badan usaha yang menghimpun dana dari masyarakat dalam bentuk simpanan dan menyalurkannya kepada masyarakat dalam bentuk kredit dan bentuk lainnya dalam rangka meningkatkan taraf hidup rakyat banyak. Kegiatan bank secara umum dibagi menjadi 3 bagian diantaranya menghimpun dana (Funding), menyalurkan dana (Lending), dan memberikan jasa-jasa lainnya (Services).

Pada tanggal 5 November 2007, Bapak Presiden Republik Indonesia Susilo Bambang Yudhoyono meresmikan Kredit Usaha Rakyat (KUR) dengan fasilitas penjaminan kredit dari pemerintahan melalui perusahaan penjamin KUR merupakan fasilitas pembiayaan yang dapat diakses oleh Usaha Mikro, Kecil, Menengah dan Koperasi (UMKMK) yang memiliki usaha yang layak namun belum bankable, dimana usaha tersebut memiliki prospek bisnis yang baik dan memiliki kemampuan mengembalikan kredit, namun mengalami keterbatasan dalam hal memenuhi persyaratan agunan, perizinan formal dan sebagainya. UMKMK yang diharapkan 
dengan mengakses KUR adalah yang bergerak di sektor usaha produktif antara lain: pertanian, perikanan dan pelaut, perindustrian, kebutuhan dan jasa keuangan simpan pinjam. Penyaluran KUR dapat dilakukan langsung yaitu UMKMK dapat langsung mengakses KUR di Kantor Cabang atau Kantor Cabang Pembantu Bank Pelaksana dan dapat juga dilakukan secara tidak langsung yaitu UMKMK dapat mengakses KUR melalui Lembaga Keuangan Mikro dan Koperasi, atau melalui kegiatan lingkage program lainnya yang bekerjasama dengan Bank Pelaksana.

Sumatera Barat merupakan daerah yang potensial untuk penyaluran KUR karena sebagian besar usaha produktif di Sumatera Barat terdiri dari Usaha Mikro Kecil Menengah Dan Koperasi (UMKMK). Dengan keikutsertaan PT. Bank Pembangunan Daerah Sumatra Barat khususnya Bank Nagari Cabang Lubuk Gadang sebagai Bank Pelaksana KUR diharapkan mampu memberikan kontribusi terhadap pengembangan sektor rill dan program-program pengentasan kemiskinan, pengaruh tingkat pengangguran dan perluasan lapangan pekerjaan serta peningkatan taraf hidup masyarakat.

Kredit Usaha Rakyat (KUR) ini ditujukan untuk membantu ekonomi usaha rakyat kecil dengan cara memberikan pinjaman untuk usaha yang didirikannya. Di dalam memberikan kredit, pihak bank harus memiliki prosedur-prosedur kredit yang akan menjadi pedoman didalam memberikan suatu kredit. Proses pemberian kredit membutuhkan pertimbangan dan analisis. Atas diajukannya permohonan peminjaman kredit tersebut, tentu saja harus mengikuti berbagai prosedur yang ditetapkan oleh bank yang bersangkutan. Selain itu, pemohon harus mengetahui hak dan kewajiban yang akan timbul dari masing-masing pihak yaitu debitur dan kreditur.

Persoalan program KUR tidak hanya sekedar tertuju pada suku bunga yang belum bisa menolong para UMKMK, tapi juga terhambat pada penyalururan yang tidak bisa menjangkau sepenuhnya pada usaha kecil yang memang membutuhkan dana. Penyebab rendahnya daya serap KUR belakangan ini karena persyaratan yang tidak bisa dipenuhi oleh pelaku UMKMK. Tentu saja penyebabnya adalah tingkat suku bunga yang tidak kompentitif. Adapun kendala dalam pemberian kredit ini yaitu usaha yang dijalankan oleh nasabah mengalami penurunan atau kebangkrutan sehingga kemampuan untuk membayar pinjaman tidak ada, hal ini mengakibatkan adanya kredit macet.

Setiap bank pasti menghadapi masalah kredit macet. Bank tanpa kredit bermasalah merupakan hal yang aneh, (kecuali bank-bank yang baru tentunya). Membicarakan kredit macet, sesungguhnya membicarakan risiko yang terkandung dalam setiap pemberian kredit, dengan demikian bank tidak mungkin terhindar dari kredit bermasalah. Suatu lembaga keuangan atau bank akan memberikan kredit kepada peminjam jika betul-betul yakin bahwa sipenerima kredit akan mengembalikan pinjaman yang diterimanya sesuai dengan jangka waktu dan syarat yang telah disetujui oleh kedua belah pihak. Bila ada satu atau beberapa debitur Bank Nagari Cabang Lubuk Gadang tidak memenuhi aturan tersebut, maka dapat menimbulkan dampak dikemudian hari, yaitu kredit yang diberikan tidak sesuai dengan waktu yang telah diberikan atau kredit yang diberikan.

Dalam memberikan kredit bank harus memperhatikan asas-asas pemberian kredit. Pihak bank harus melakukan penelitian terlebih dahulu pada calon debitur, seperti mengetahui watak (character), kemampuan (capacity), modal (capital), agunan (collateral) dan kondisi ekonomi debitur (condition of economy).

Dengan ditetapkannya peraturan pelaksanaan KUR dan kebijakan pendukungnya, maka di harapkan penyaluran KUR oleh Bank Nagari dapat berjalan 
dengan baik dan didukung serta dilaksanakan sepenuhnya oleh pelaksana/pejabat perkreditan sehingga rencana penyaluran KUR tersebut dapat direalisir sebagaimana yang dihapakan. Bertitik tolak dari uraian diatas penulis tertarik untuk membahas tingkat lanjut mengenai prosedur pelaksanaan Kredit Usaha Rakyat (KUR) dalam pemberian kreditnya. Permasalahan ini penulis susun dalam bentuk proposal dengan judul Prosedur Pelaksaan Kredit Usaha Rakyat Pada Bank Nagari Cabang Lubuk Gadang.

Berdasarkan latar belakang yang diuraikan diatas maka dapat dirumuskan permasalah sebagai berikut. Bagaimana prosedur pelaksanaan Kredit Usaha Rakyat (KUR) yang dilakukan oleh Bank Nagari Cabang Lubuk Gadang dan hal-hal apa saja yang diperlukan oleh debitur untuk mendapatkan KUR?

Berdasarkan rumusan masalah, maka tujuan penelitian ini adalah: Untuk mengetahui bagaimana prosedur pelaksanaan pemberian Kredit Usaha Rakyat (KUR) yang ditetapkan Bank Nagari Cabang Lubuk Gadang dalam pemberian kreditnya dan hal-hal apa saja yang diperlukan dalam prosedur pelaksanaan kreditnya pada debitur.

\section{LANDASAN TEORI}

Pengertian Bank

Menurut Black Henry Campbell seperti yang dikutip oleh (Hermansyah, 2008: 30), memberi arti kepada bank sebagai suatu instalasi yang mempunyai peran besar dalam dunia komersil yang mempunyai wewenang untuk menerima deposito, memberikan pinjaman, menerbitkan promissory notes, yang sering disebut dengan bank bills atau notes, namun demikian fungsi bank original adalah hanya menerima deposito berupa uang logam, plate, emas dan lain-lain.

Pasal 1 undang-undang nomor 10 tahun 1998 tentang perubahan atas undangundang nomor 7 tahun 1992 tentang perbankan menyebutkan bahwa: bank adalah badan usaha yang menghimpun dana dari masyarakat dalam bentuk simpanan dan menyalurkannya kepada masyarakat dalam bentuk kredit dan bentuk lainnya dalam rangka meningkatkan taraf hidup rakyat banyak.

Berdasarkan pengertian diatas dapat diambil kesimpulan bahwa bank adalah suatu lembaga yang berfungsi dan berwenang untuk menghimpun dana dari masyarakat dan menyalurkan dana kepada kepada masayarakat yang membutuhkankan dengan tujuan untuk mendapatkan keuntungan bersama.

\section{Jenis-jenis Bank}

Pasal 5 Undang-Undang nomor 7 tahun 1992 tentang perbankan, menurut jenisnya bank terdiri atas:

1. Bank Umum

Bank yang melaksanakan usaha secara konvensional dan berdasarkan prinsip syariah yang dalam kegiatannya memberikan jasa dalam memberikan pembayaran.

2. Bank Perkreditan Rakyat

Bank Perkreditan Rakyat adalah bank yang melaksanakan kagiatan usaha secara konvensional atau berdasarkan prinsip syariah yang dalam kegiatannya tidak memberikan jasa dalam lalu linta pembayaran.

\section{Usaha Bank}

Sesuai dengan pasal 6 Undang-Undang nomor 7 tahun 1992 tentang perbankan sebagaimana yang telah diubah dalam undang-undang nomor 10 tahun 1998, maka usaha-usaha yang dapat dilakukan oleh bank meliputi: 
1. Menghimpun dana dari masyarakat dalam bentuk simpanan berupa giro, deposito berjangjka, sertifikat deposito, tabungan dan bentuk lainnya yang dipersamakan dengan itu.

2. Memberikan kredit

3. Memberikan surat pengakuan hutang

4. Membeli, menjual dan menjamin atas resiko sendiri maupun untuk kepentingan dan atas nasabahnya :

a. Kertas pembendaharaan Negara dan surat jaminan pemerintah

b. Sertifikat Bank Indonesia

c. Obligasi

d. Surat dagang yang berjangka waktu dengan 1 (satu) tahun

e. Instrumen surat berharga lain yang berjangka waktu sampai dengan 1 (satu) tahun.

1) Memindahkan uang baik demi kepentingan sendiri maupun kepentingan nasabah.

2) Menempatkan dana atau meminjamkan dana pada bank lain, baik menggunakan surat, sarana telekomunikasi maupun dengan wesel, cek atau sarana lainnya.

3) Menerima pembayaran dari tagihan atas surat berharga dengan melakukan hitungan dengan antar pihak ketiga.

4) Menyediakan tempat untuk menyimpan barang atau surat berharga.

5) Melakukan kegiatan penitipan untuk kepentingan pihak lain berdasarkan suatu kontrak.

6) Melakukan penempatan dana dari nasabah kepada nasabah lain dalam bentuk surat berharga yang tidak tercatat dalam bursa efek.

7) Menyediakan pembiayaan dan melakukan kegiatan lain berdasarkan syariah, sesuai ketentuan yang ditetapkan bank Indonesia.

\section{Pengertian Kredit}

Kredit, menurut UU No. 7/1992 tentang pokok-pokok Perbankan adalah "penyediaan uang atau tagihan yang dapat dipersamakan dengan itu, berdasarkan persetujuan atau kesepakatan pinjam-meminjam antara bank dengan pihak lain yang mewajibkan pihak peminjam untuk melunasi hutangnya setelah jangka waktu tertentu dengan bunga, imbalan, atau pembagian hasil keuntungan".

Menurut Undang-Undang Perbankan No. 10 Tahun 1998, pembiayaan Kredit adalah penyediaan uang atau tagihan yang dapat dipersamakan dengan itu, berdasarkan persetujuan atau kesepakatan antara bank dan pihak lain yang dibiayai untuk mengembalikan uang atau tagiahan tersebut setelah jangka waktu tertenu dengan imbalan atau bagi hasil. Pembiayaan berbeda dengan kredit terutama dari imbalan yang diterima oleh bank. Bank konvensional mendapatkan imbalan berupa bunga sementara bank syariah mendapatkan imbalan berupa bagi hasil dari debitur.

Menurut Kasmir (2012 : 112) Kata kredit berasal dari bahasa Latin Creder yang berarti percaya. Maksudnya si pemberi kredit percaya kepada si penerima kredit, bahwa kredit yang disalurkan pasti akan dikembalikan sesuai perjanjian. Sedangkan bagi si penerima kredit berarti menerima kepercayaan, sehingga mempunyai kewajiban untuk membayar kembali pinjaman tersebut sesuai dengan jangka waktu. Oleh karena itu, untuk meyakinkan bank bahwa nasabah benar-benar dapat dipercaya, maka sebelum kredit diberikan terlebih dahulu bank mengadakan analisis kredit 
Bila dikaitkan dengan kegiatan usaha, kredit berarti suatu kegiatan memberikan nilai ekonomi (economic value) kepada seseorang atau badan usaha berlandaskan kepercayaan saat itu, bahwa nilai ekonomi yang sama akan dikembalikan kepada kreditur (bank) setelah jangka waktu tertentu sesuai dengan kesepakatan yang telah disetujui ana kreditur (bank) dan debitur (user). Sedangkan pengertian pembiayaan adalah penyediaan uang atau tagihan yang dapat dipersamakan dengan itu, berdasarkan persetujuan atau kesepakatan antara bank dengan pihak lain yang mewajibkan pihak yang dibiyai untuk mengembalikan uang atau tagihan uang tersebut setelah jangkawaktu tertentu dengan imbalan atau bagi hasil.

\section{Tujuan dan Fungsi Kredit}

Perkreditan pada umumnya mempunyai peranan bagi bank karena merupakan kekayaan utama dan salah satu sumber penghasilan utama. Dilain segi, kredit merupakan kekayaan bank yang mengandung resiko, untuk mengatasi resiko tersebut maka setiap personil yang mengatasi perkreditan ini harus tetap berpedoman apakah nasabah yang akan menerima kredit tersebut mampu dan mau mengembalikan kredit yang diterimanya.

Menurut Kasmir (2012 : 116) Tujuan dan pemberian kredit, adapun tujuan utama dari pemberian kredit adalah :

1. Mencari keuntungan

Yaitu bertujuan untuk memperoleh hasil dari pemberian kredit, keuntungan ini berupa bunga yang diperoleh oleh bank atas balas jasa dan biaya administrasi.

2. Membantu usaha nasabah

3. Bank akan membantu usaha nasabah yang memerlukan dana, baik dana untuk investasi maupun modal kerja.

4. Membantu Pemerintah

5. Bagi pemerintah semakin banyak kredit yang disalurkan pihak bank, maka semakin baik karena hal ini menunjukan peningkatan diberbagai sector.

Sedangkan fungsi kredit menurut Ismail (2010 : 96) yaitu pelayanan kepada masyarakat dalam memenuhi kebutuhan untuk meningkatkan usahanya. Masyarakat di sini merupakan individu, pengusaha, lembaga, dan badan usaha yang membutuhkan dana. Kredit berfungsi membantu masyarakat dalam memenuhi kebutuhn melalui penyaluran dana yang diberikan oleh bank. Fungsi kredit secara terperinci adalah sebagai berikut :

1. Kredit dapat meningkatkan arus tukar-menuka barang dan jasa. Kredit dapat meningkatkan arus tukar-menuka barang, ini seandainya belum tersedia uang sebagai alat pembayara,maka kredit akan membantu melancarkan lalu lintas pertukaran barang dan jasa.

2. Kredit merupakan alat yang dipakai untuk memanfaatkan idle fund. Di dalam kehidupan ekonomi, ada beberapa pihak yang kelebihan dana, dan ada pula beberapa pihak yang kekurangan dana. Kredit merupakan suatu cara untuk mengatasi masalah tersebut. Satu pihak kelebihan dana dan tidak dapat memanfaatkan dana tersebut sehingga dananya menjadi idle, sementara ada pihak yang mempunyai usaha akan tetapi tidak memiliki dana yang cukup untuk mengembangkan usahanya, sehingga memerlukan dana.

3. Kredit dapat menciptakan alat pembayaran yang baru. Sebagai contoh adalah kredit rekening koran yang diberikan oleh bank kepada usahawan. Pada dasarnya saat bank telah melakukan perjanjian kredit rekening koran, pada saat itu debitur sudah memiliki hak untuk menarik dana tersebut secara tunai dari rekening gironya. 
4. Kredit dapat meningkatkan peredaran dan lalu lintas uang. Kredit uang disalurkan melalui giro dapat menciptakan pembayaran baru seperti cek, giro, bilyet dan wesel, sehingga apabila pembayaran-pembayaran dilakukan dengan cek, giro, bilyet dan wesel maka dapat meningkatkan uang giral. Disamping itu, kredit perbankan yang ditarik secara tunai dapat pula meningkatkan peredaran uang kartal, sehingga arus lalu lintas uang akan berkembang pula.

5. Kredit sebagi salah satu alat stabilitas ekonomi. Dalam keadaan ekonomi yang kurang sehat, kebijakan diarahkan kepada usaha-usaha antara lain:

a. Pengendalian inflasi,

b. Peningkatan ekspors,

c. Pemenuhan kebutuhan pokok rakyat.

\section{Unsur-unsur Kredit}

Dalam kata kredit terkandung unsur-unsur yang direkatkan menjadi satu. Sehingga jika kita bicara kredit maka termasuk membicarakan unsur-unsur yang terkandung didalamnya.

Menurut Kasmir (2008 : 74), adapun unsur-unsur yang terkandung dalam pemberian suatu fasilitas kredit adalah sebagai berikut :

1. Kepercyaan

Yaitu suatu keyakinan pemberi kredit (bank) bahwa kredit yang diberikan baik berupa uang, barang, atau jasa akan benar-benar diterima kembali dimasa yang akan dating. Kepercayaan ini diberikan oleh bank karena sebelum dana diluncurkan, sudah dilakukan penelitian dan penyelidikan yang mendalam pada nasabah.

2. Kesepakatan

Di samping unsur kepercayaan didalam kredit juga mengandung unsur kesepakatan antara si pembeli dengan si penerima kredit. Kesepakataan penyaluran kredit dituangkan dalam akad kredit yang ditandatangani oleh kedua belah pihak, yaitu pihak bank dan nasabah.

3. Jangka waktu

Setiap kredit yang diberikan pasti memiliki jangka waktu tertentu, jangka waktu ini mencakup masa pengembalian kredit yang telah disepakati.

4. Risiko

Faktor risiko kerugian dapat diakibatkan oleh dua hal, yaitu risiko kerugian yang diakibatkan nasabah sengaja tidak mau membayar kreditnya padahal mampu dan risiko kerugian yang diakibatkan oleh nasabah yang tidak sengaja yaitu seperti terjadinya musibah terjadinya bencana alam.

5. Balas jasa

Akibat dari pemberian fasilitas kredit bank tentu mengharapkan suatu keuntungan dalam jumlah tertentu. Disebut bunga bagi bank.

\section{Jenis-jenis Kredit}

Menurut Kasmir (2012 : 119), beragamnya jenis usaha menyebabkan beragam pula kebutuhan akan dana. Kebutuhan dana yang beragam menyebabkan jenis kredit juga beragam. Hal ini disesuaikan dengan kebutuhan dana yang diinginkan nasabah. Dalam praktiknya kredit yang diberikan bank umum dan bank perkreditan rakyat untuk masyarakat terdiri dari berbagai jenis. Secara umum jenis-jenis kredit dapat dilihat dari berbagai segi antara lain :

1. Dilihat dari Segi Keuangan 
a. Kredit Investasi yaitu kredit investasi merupakan kredit jangka panjang yang biasanya digunakan untuk keperluan perluasan usaha.

b. Kredit modal kerja

Kredit modal kerja merupakan kredityang digunakan untuk keperluan meningkatkan produksi dalam operasionalnya.

2. Dilihat dari Segi Tujuan Kredit

a. Kredit produktif yaitu kredit yang digunakan untuk peningkatan usaha atau produksi dan investasi. Kredit ini diberikan untuk menghasilkan barang dn jasa.

b. Kredit konsumtif yaitu kredit yang digunakan untuk komsumsi secara pribadi. Dalam kredit ini tidak ada pertambahan barang dan jasa yang dihasilkan, karena memang digunakan untuk seseorang atau badan usaha.

c. Kredit perdagangan yaitu merupakan kredit yang diberikan kepada pedagang dan digunkan untuk membiayai aktivitas perdagangan seperti untuk membeli barang dagangan yang pembayaran diharapkan dari hasil penjualan barang dagangan tersebut.

3. Dilihat dari Segi Jangka Waktu

a. Kredit jangka pendek

Merupakan kredit yang memiliki jangka waktu kurang lebih satu tahun atau paling lama satu tahun dan biasanya digunakan untuk keperluan modal kerja.

b. Kredit jangka menengah Jangka kreditnya berkisar antara satu tahun sampai dengan tiga tahun dan biasanya kredit ini digunakan untuk melakukan investasi.

c. Kredit jangka panjang Merupakan kredit yang masa pengembaliannya paling panjang. Kredit jangka panjang waktu pengembaliannya diatas tiga tahun atau lima tahun.

4. Dilihat dari Segi Jaminan

a. Kredit dengan jaminan

Merupakan kredit yang diberikan dengan suatu jaminan. Jaminan tersebut dapat berbentuk barang berwujud atau tidak berwujud atau jaminan orang.

b. Kredit tanpa jaminan

Merupakan kredit yang diberikan tanpa jaminan barang atau orang tertentu. Kredit jenis ini diberikan dengan melihat prospek usaha, karakter serta loyalitas atau nama baik si calon debitur selama berhubungan dengan bank atau pihak lainnya.

5. Dilihat dari Segi Sektor Usaha

a. Kredit pertanian

Merupakan kredit yang dibiayai untuk sektor perkebunan atau pertanian. Sektor usaha pertanian dapat berupa jangka pendek dan jangka panjang.

b. Kredit peternakan

Merupakan kredit yang diberikan untuk sektor peternakan baik jangka pendek misalnya untuk peternakan ayam dan jangka panjang misalnya untuk ternak kambing atau ternak sapi.

c. Kredit industry

Merupakan kredit yang diberikan untuk membiayai industri, baik industri kecil, menengah dan besar.

d. Kredit pertambangan 
Merupakan kredit yang diberikan kepada usaha tambang. Jenis usaha tambang yang dibiayai biasanya dalam jangka panjang, seperti tambang emas, minyak atau timah

e. Kredit pendidikan

Merupakan kredit yang diberikan untuk membangun sarana dan prasarana pendidikan atau dapat pula berupa kredit untuk mahasiswa.

f. Kredit perumahan

Yaitu kredit yang membiayai pembangunan atau pembelian perumahan dan biasanya berjangka panjang.

\section{METODE PENELITIAN}

Dalam metode pengumpulan data dan bahan untuk melakukan penelitian ini, penulis menggunakan metode-metode pengumpulan data, sebagai berikut :

1. Metode Pengumpulan Data

a. Study Kepustakaan (Library Research)

Penulis dalam menyelasaikan proposal ini melakukan study kepustakaan, membaca berbagai buku-buku referensi yang berhubungan dengan Kredit Usaha Rakyat (KUR) agar proposal ini menjadi lebih baik dan sempurna dalam penyajiannya.

b. Study Lapangan (Field Research)

Dalam proses penyelesaian proposal ini penulis melakukan studi lapangan dengan mendatangi langsung Bank Nagari Cabang Lubuk Gadang untuk meneliti dan mendalami tentang prosedur Kredit Usaha Rakyat (KUR) yang diberikan oleh Bank Nagari Cabang Lubuk Gadang.

2. Metode Analisa Data

Dalam menyelesaiakan proposal ini penulis menggunakan analisa data kualitatif. Dimana metode kualitatif menggambarkan, memahami dan menjelaskan data yang diteliti selama penelitian berlangsung.

\section{HASIL DAN PEMBAHASAN \\ Pengertian Prosedur}

Prosedur merupakan langkah yang dilaksanakan untuk menyelesaikan kegiatan atau aktivitas, sehingga dapat mencapai tujuan yang diharapkankan secara efektif dan efesien serta dapat dengan mudah menyelesaikan suatu masalah yang terperinci menurut waktu yang telah ditentukan.

Prosedur menurut Mulyadi (2001: 5) adalah suatu urutan kegiatan klerikal, biasanya melibatkan beberapa orang dalam satu departemen atau lebih, yang dibuat untuk menjamin penanganan secara seragam transaksi perusahaan yang terjadi berulang-ulang.

\section{Karakteristik Prosedur}

Beberapa karakteristik prosedur antara lain:

1. Prosedur menunjang tercapainya suatu organisasi.

2. Prosedur mampu menciptakan adanya pengawasan yang baik dan menggunakan biaya yang seminimal mungkin.

3. Prosedur menunjukan urutan-urutan yang logis dan sederhana.

4. Prosedur menunjukan adanya penetapan keputusan dan tanggung jawab.

5. Prosedur menunjukan tidak adanya keterlambatan atau hambatan.

6. Adanya suatu pedoman kerja yang harus diikuti oleh anggota-anggota organisasi.

7. Prosedur mencegah terjadinya penyimpanan. 
8. Membantu efesiensi, efektifitas dan produktifitas kerja dari suatu organisasi.

\section{Manfaat Prosedur}

Suatu prosedur dapat memberikan manfaat sebagai berikut:

1. Lebih memudahkan dalam menentukan langkah-langkah kegiatan dimasa yang akan datang.

2. Mengubah pekerjaan berulang-ulang menjadi rutin sehingga menyederhanakan pelaksanaan dan untuk selanjutnya mengerjakan seperlunya saja.

3. Adanya suatu petunjuk atau program kerja yang jelas dan harus dipatuhi oleh seluruh pelaksana.

4. Membantu dalam usaha meningkatkan produktifitas kerja yang efektif dan efisien.

5. Mencegah terjadinya penyimpangan dan memudahkan dalam pengawasan, bila terjadi penyimpangan akan dapat segera diadakan perbaikan-perbaikan sepanjang dalam tugas dan fungsinya masing-masing

\section{Pengertian KUR}

Kredit Usaha Rakyat (KUR) adalah kredit/pembiayaan modal kerja dan investasi kepada usaha mikro kecil menengah dan koperasi (UMKMK) dibidang usaha dan produktif dengan pemberian melalui pola langsung, secara tidak langsung dengan cara executing/channeling dan KUR tersebut dijamin oleh perusahaan penjamin.

Dilihat dari pengertian diatas tentu kredit ini di khususkan pada usaha Mikro. Usaha Keil, dan Usaha Menengah yang meliputi:

1. Usaha mikro adalah usaha produktif milik perorangan atau badan usaha perorangan yang memiliki kriteria:

a. Memiliki kekayaan bersih paling banyak Rp. 50.000.000,- (Lima puluh juta rupiah)

b. Memiliki hasil penjualan tahunan paling banyak Rp. 300.000.000,- (Tiga ratus juta rupiah)

2. Usaha kecil adalah usaha ekonomi produktif yang berdiri sendiri, yang dilakukan oleh orang perorangan atau badan usaha yang bukan merupakan anak perusahaan yang dimiliki, dikuasai atau menjadi bagian baik langsung maupun tidak langsung dari usaha menengah atau usaha besar yang memenuhi kriteria:

a. Memiliki kekayaan lebih dari Rp. 50.000.000,- (Lima puluh juta rupiah) sampai dengan yang paling banyak Rp. 500.000.000,-(Lima ratus juta rupiah) termasuk tanah dang bangunan usaha.

b. Memiliki hasil penjualan tahunan lebih dari Rp. 300.000.000,- (Tiga ratus juta rupiah) sampai dengan paling banyak Rp. 2.500.000.000,- (Dua miliar lima ratus juta rupiah).

3. Usaha menengah adalah usaha ekonomi produktif yang berdiri sendiri, yang dilakukan oleh orang perorangan atau badan usaha yang bukan merupakan anak perusahaan atau cabang perusahaan yang dimiliki, dikuasai atau menjadi bagian baik langsung maupun tidak langsung dari usaha besar yang memenuhi kriteria:

a. Memiliki kekayaan bersih Rp. 500.000.000,- (Lima ratus juta rupiah) sampai dengan paling banyak Rp. 10.000.000.000,- (Sepuluh miliar rupiah) termasuk tanah dan bangunan tempat usaha.

b. Memiliki hasil penjualan lebih dari Rp. 2.500.000.000,- (Dua miliar lima ratus juta rupiah) sampai dengan paling banyak Rp. 50.000.000.000, (Lima puluh miliar rupiah). 


\section{Prinsip Dasar Pemberian KUR}

Suatu lembaga perbankan dalam pemberian kreditnya memiliki beberapa prinsip dasar yaitu sebagai berikut :

\section{Prinsip 5C}

Menurut Maryanto (2011 : 161) "5C" ini merupakan suatu alat atau "tool" untuk melihat sejauh mana kelayakan kredit yang akan diberikan kepada calon debitur dan dapat dipertanggung jawabkan. Salah satu keputusan kredit ditentukan oleh prinsip " $5 \mathrm{C}$ " adalah :

a. Character (Karakter)

Karakter sangat menyangkut sifat debitur yang harus mempunyai ikhtiar baik dan komitmen tinggi untuk mengembalikan seluruh kewajiban sesuai dengan perjanjian yang telah ditandatangani bersama antara pihak debitur dan pihak kreditur. Sebagai contoh beberapa gambaran dari sifat calon debitur yang akan menentukan karakternya seperti : usia, pendidikan, status, kesehatan, pergaulan, lingkungan, tanggung jawab terhadap semua pihak yang berhubungan.

b. Capacity (Kapasitas)

Capacity dalam hal ini merupakan suatu penilaian kepada calon debitur mengenai kemampuan melunasi kewajiban-kewajibannya dari kegiatan usaha yang dilakukannya yang akan dibiayai dengan kredit dari bank. Jadi jelaslah maksud penilaian dari terhadap capacity ini untuk menilai sampai sejauh mana hasil usaha yang akan diperolehnya tersebut akan mampu untuk melunasinya tepat pada waktunya sesuai dengan perjanjian yang telah disepakati.

c. Capasital (Modal)

kondisi kekayaan yang dimiliki oleh perusahaan yang dikelolanya. Hal ini bisa dilihat dari neraca, laporan rugi-laba, struktur permodalan, ratio-ratio keuntungan yang diperoleh seperti return on equity, return on investment. Dari kondisi di atas bisa dinilai apakah layak calon debitur diberi pembiayaan, dan beberapa besar plafon pembiayaan yang layak diberikan.

d. Collateral (Jaminan)

Jaminan yang mungkin bisa disita apabila ternyata calon debitur benar-benar tidak bisa memenuhi kewajibannya. Collateral ini diperhitungkan paling akhir, artinya bilamana masih ada suatu kesangsian dalam pertimbangan-pertimbangan yang lain, maka bisa menilai harta yang mungkin bisa dijadikan jaminan.

e. Condition (Kondisi)

pembiayaan yang diberikan juga perlu mempertimbangkan kondisi ekonomi yang dikaitkan dengan prospek usaha calon debitur. Ada suatu usaha yang sangat tergantung dari kondisi perekonomian, oleh karena itu perlu mengaitkan kondisi ekonomi dengan usaha calon debitur.

\section{Prinsip 5P}

Menurut Ismail (2011 : 115) 5P itu terdiri dari :

a. Personality (Personal)

Bank mencari data tentang kepribadian calon debitur seperti riwayat hidupnya, hobi, keadaan keluarga, sosial standing, serta hal-hal lain yang erat hubungannya dengan kepribadian sipeminjam.

b. Purpose (Tujuan)

Bank mencari data tentang tujuan atau keperluan penggunaan kredit.

c. Prospect 
Bank mencari data tentang harapan masa depan dari bidang usaha atau kegiatan usaha si peminjam.

d. Payment (Pembayaran Kembali)

Bank mencari data tentang bagaimana perkiraan pembayaran kembali pinjaman yang akan diberikan.

e. Protection (Perlindungan)

Merupakan upaya perlindungan yang dilakukan bank dalam rangka berjaga-jaga apabila calon debitur tidak dapat memenuhi kewajibannya. Untuk melindungi kredit tersebut bank meminta jaminan kebendaan kepada calon nasabah.

2. Prinsip 3R

Menurut Melayu (2007 : 108) konsep lain yang perlu mendapatkan perhatian dalam pengambilan keputusan pemberian kredit adalah prinsip 3R yaitu :

a. Returns (Hasil yang dicapai)

Yaitu penilaian atas hasil yang akan dicapai oleh perusahaan calon debitur setelah mendapatkan kredit, apakah hasil tersebut cukup untuk menutup hasil pinjaman serta memungkinkan pula usahanya untuk berkembang terus.

b. Repayment (Pembayaran kembali)

Sebagai kelanjutan dari return diatas, yang kemudian diperhitungkan kemampuan, jadwal serta jangka waktu pengembalian kembali kredit.

c. Risk Bearing Ability (Kemampuan untuk menanggung risiko)

Yaitu sejauh mana ketahanan suatu perusahaan calon debitur untuk menanggung resiko kegagalan andaikata terjadi suatu hal dikemudian hari yang tidak diinginkan.

\section{Pola KUR}

1. Pemberian KUR dapat dilakukan secara langsung kepada debitur, pola secara langsung ini dapat dilakukan sebagai berikut:

a. Bank melakukan penilaian secara individu terhadap calon debitur KUR, apabila di nilai layak dan disetujui oleh bank, maka debitur KUR menandatangani perjanjian kredit secara langsung dengan bank.

b. Bank mengajukan permohonan pinjaman dengan maksimal pinjaman sebesar $70 \%$ dari plafond kredit yang diberikan dan selanjutnya perusahaan penjamin menerbitkan serfitikat pinjaman.

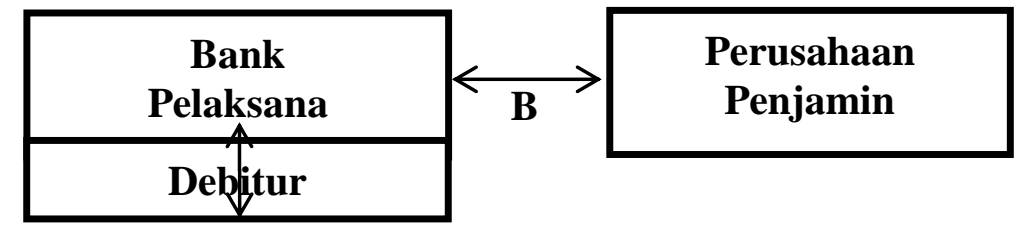

Gambar 1 : Skema gambaran KUR

2. Pemberian KUR secara tidak langsung melalui lembaga linkage

a. Lembaga linkage sebagai debitur mengajukan permohonan kredit/pembiayaan kepada bank.

b. Bank melakukan penilaian atau analisa kenyataan. Jika hal ini dinyatakan layak maka bank memberikan persetejuan dan penandatanganan perjanjian kredit atau pembiayaan dilakukan antara bank dan lembaga linkage.

c. Bank mengajukan permintaan penjaminan kredit atau pembiayaan kepada perusahaan penjamin, selanjutnya perusahaan penjamin menerbitkan sertifikat penjamin atas nama lembaga linkage. 
d. Lembaga linkage menyalurkan kredit atau pembiayaan yang diterima dari bank kepada UMKMK dari lembaga linkage.

e. UMKMK melakukan pembayaran cicilan kepada lembaga Lingkage.

f. Lembaga linkage melakukan pembayaran kewajiban kredit/pembiayaan kepada bank.

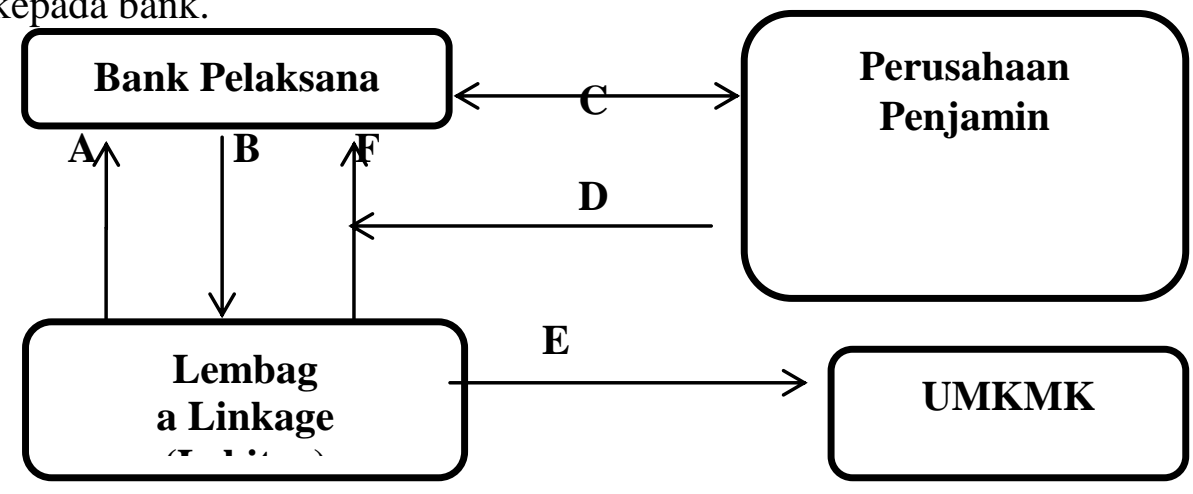

Gambar 2 : Skema pemberian KUR secara tidak langsung melalui lembaga linkage

\section{Prosedur Pelaksanaan KUR pada Bank Nagari Cabang Lubuk Gadang}

Berdasarkan hasil penelitian penulis di Bank Nagari Cabang Lubuk Gadang, pada saat praktek kerja lapangan atau (magang) serta hasil wawancara yang dilakukan penulis dengan Kepala Unit, analisi kredit (account officer AO) serta dengan nasabah KUR, maka penulis dapat mengemukakan bahwa proses pemberian KUR dilakukan secara bertahap yaitu sebagai berikut :

1. Calon debitur mendatangi kantor Bank kemudian meminta informasi tentang fasilitas kredit pada bank tersebut, maka bagian administrasi akan menjelaskan tentang persyaratan kepada calon debitur kredit. Setelah calon debitur menyetujui hal yang disyaratkan bank dan debitur berusaha melengkapi hal yang disyaratkan tersebut.

2. Bagian administrasi kredit bank menerima lampiran permohonan kredit secara tertulis, yang dilengkapi dengan dokemen dan data yang diperlukan bank seperti bukti identitas diri berupa fotokopi Kartu Tanda Penduduk (KTP), fotokopi Kartu Keluarga (KK), surat keterangan usaha dan pas foto serta calon debitur dan disertai dengan surat-surat jaminan yang disyaratkan pihak bank.

3. Bagian administrasi kredit memeriksa kelengkapan lampiran permohonan kredit calon debitur apakah sudah sesuai dengan hal-hal yang disyaratkan.

4. Setelah mendapatkan pengesahan dari bagian administrasi, kreditur melampirkan permohonan calon debitur pada account officer untuk menganalisa kebenaran persyaratan yang telah dipenuhi. account officer melakukan pengecekan, kelengkapan terhadap jaminan dan melakukan penilaian dengan menggunakan prinsip 5C. Setelah syarat-syarat dilengkapi, dalam hal ini account officer akan melakukan checking serta peninjauan langsung ke lapangan tentang layak atau tidaknya calon debitur untuk mendapatkan kredit.

5. Account officer mengirimkan lampiran tersebut kepada komite kredit untuk dibahas dalam rapat persetujuan pemberian kredit.

6. Komite kredit mempertimbangkan persetujuan kredit harus berdasarkan analisa kredit yang tajam, data lengkap, akurat, relevan dengan bidang usaha objektif. 
7. Jika Komite kredit telah menyetujui permohonan pinjaman yang diajukan oleh calon debitur maka pinjaman tersebut bisa dicairkan.

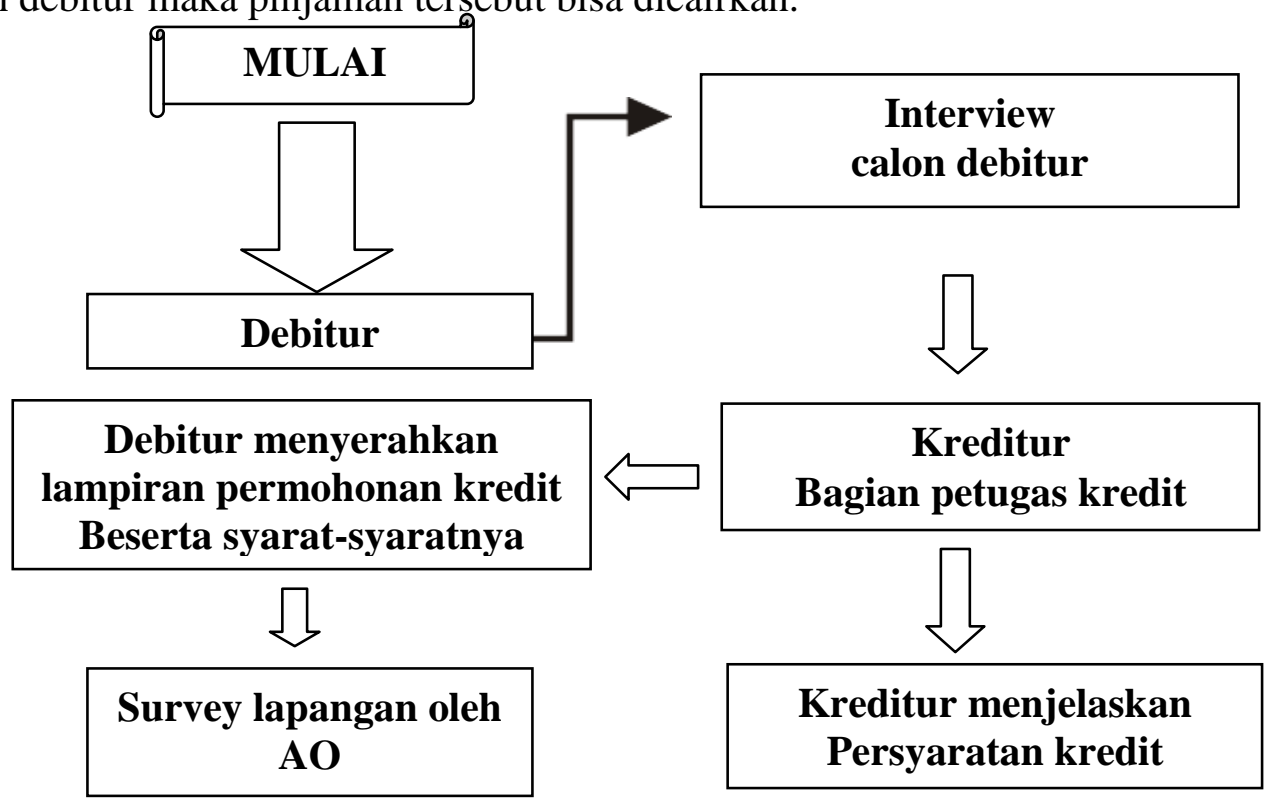

Gambar 3 : Flowchart rangkaian analisis kredit pada Bank Nagari Cabang Lubuk Gadang

\section{Pengawasan Kualitas KUR}

Menurut Herman (2012 : 126) mempertahankan kualitas kredit dengan baik jauh lebih penting dari pada menciptakan kredit baru. Pemberian kredit tanpa mempertimbangkan kualitas kredit, bisa menyebabkan kerugian besar dikemudian hari. Langkah pengamanan untuk mengurangi timbulnya kredit bermasalah adalah sistim pengawasan yang efektif.

Bank secara periodik melaporkan kualitas aktiva produktif kepada Bank Indonesia dan kepada publik melalui laporan keuangannya. Dalam laporannya itu kualitas kredit dibagi atas lima tingkat, yaitu :

1. Lancar (L), yaitu apabila tidak terdapat tunggakan pembayaran pinjaman baik pokok ataupun bunga.

2. Dalam Perhatian Khusus (DPK), yaitu apabila terdapat tunggakan pinjaman pembayaran pokok dan atau bunga sampai dengan 90 hari.

3. Kurang Lancar (KL), yaitu apabila terdapoat tunggakan pembayaran pokok dan atau bunga sampai dengan 120 hari.

4. Diragukan (D), yaitu apabila terdapat tunggakan pembayaran pinjaman baik pokok dan atau bunga sampai dengan 180 hari.

5. Macet (M), yaitu apabila terdapat tunggakan pembayaran pokok dan atau bunga diatas 180 hari.

Banyak cara yang dilakukan bank dalam mengawasi kreditnya yang beredar. Kebanyakan dari cara pengawasan tersebut dapat dijalankan dengan akal sehat saja. Lain-lainnya dapat didasarkan atas cara-cara tradisional.tiga konsep penting sebagai dasar kontrol seperti ini adalah :

1. Pertambahan risiko kredit bisa dibatasi dengan memperpendek jangka waktu kredit. 
2. Informasi dipersiapkan oleh perusahaan harus sedemikian rupa, hingga pihak bank akan selalu mengawasi munculnya kesukaran-kesukaran uang sedini mungkin.

3. Dalam peristiwa kesukaran uang bank-bank mengusahakan dapat melaksanakan opsi untuk menarik kredit tersebut.

\section{Sistim Pengendalian KUR}

Tujuan dari sistim pengendalian kredit KUR adalah untuk menjaga keamanan dan pribadi milik perusahaan, memeriksa ketelitian dan kebenaran data akuntansi kredit bank, memajukan efesiensi dalam operasional pengendalian kredit dan membantu menjaga dipatuhi kebijaksaan perjanjian kredit antara pihak bank dengan debitur yang telah ditetapkan terlebih dahulu.

Tanggung jawab untuk menyusun suatu sistim pengendalian kredit KUR terletak pada manajemen bank. Subjek pengendalian kredit oleh manajemen bank terdiri dari bagian administrasi kredit, bagian petugas kredit, bagian dana, Direktur utama

Tujuan dilakukannnya pengendalian KUR adalah :

1. Menjaga keamanan dana milik pribadi perusaahan yang telah disalurkan pada masyarakat.

2. Memeriksa ketelitian dan kebenaran akuntasi.

3. Memajukan efesiensi dalam opersioanal sistim pengendalian kredit.

4. Membantu menjaga agar tidak ada penyimpangan dari kebijaksanaan perjanjian kredit yang telah disepakati.

Unsur pokok sistim pengendalian KUR pada Bank Nagari Cabang Lubuk Gadang adalah :

1. Struktur organisasi yang memisahkan tanggung jawab nasional secara tegas.

2. Sistim wewenang dan prosedur pencatatan, pengiktisaran, pelaporan dan pemeriksaan terhadap data keuangan pemberi kredit yang relevan dan dapat dipercaya.

3. Praktek yang sehat dalam melaksakan tugas dan fungsi setiap unit organisasi.

4. Karyawan dan elemen bagian unit organisasi yang terlihat dalam sistim pengendalian kredit mutunya sesuai dengan tanggung jawabnya.

Sistim pengendalian kredit terhadap para debitur Bank Nagari Cabang Lubuk Gadang, permasalahan yang dihadapi dalam pengembalian kredit para debitur tidaklah selalu berjalan lancar melainkan sering terjadi banyak kendala yang dihadapi, baik yang berasal dari pihak bank maupun dari pihak debitur itu sendiri.

Permasalah yang timbul dari pihak bank antara lain :

1. Kurang telitinya pihak bank dalam menyeleksi calon debitur dan adanya pemberian tambahan kredit sehingga terjadinya kredit macet.

2. Adanya perpanjangan jangka waktu tanpa memperhatikan prospek usaha dan kesanggupan debitur, sehingga menimbulkan kredit macet dan penyelesaian yang lama.

Sehingga permasalahn yang timbul dari pihak debitur antara lain :

1. Sering kali debitur tidak memberikan informasi yang benar, terutama yang berkaitan dengan jaminan atau sumber dananya.

2. Debitur tidak mampu menggunakan dana tersebut secara efektik dan efesien, sehingga sering terjadi kekurangan dana dan keterlambatan pengembalian kredit.

3. Debitur sengaja atau tidak sengaja terlambat melunasi kewajiban kepada bank, sehingga pelunasan kredit tidak tepat pada waktu yang telaah disepakati. 
Suatu pemberian kredit dianggap sukses apabila penerimaan kredit atau debitur yang bersangkutan dapat melunasi pinjaman berikut bunga tepat diberikan pada waktu yang telah ditentukan.

Berikut prosedur penaggulangan kredit macet pada Bank Nagari Cabang Lubuk Gadang :

1. Petugas kredit Bank Nagari Cabang Lubuk Gadang akan mengunjungi dan menghubungi debitur jika telah menunggak, dan apabila belum ada pelunasan sesuai dengan persetujuan kredit maka pihak bank akan mengambil jalan hokum dengan menyerahkan surat kepada kejaksaan untuk melakukan proses hokum dalam penyitaan barang jaminan dan dari barang penyitaan itu akan dilakukan pelelangan barang jaminan dari nasabah untuk dapat menutupi kerugian akibat kredit macet dari nasabah tersebut.

2. Adapun tindakan penyelamatan yang dapat dilakukan dalam penyelasaian tunggakan kredit modal kerja yang disalurkan Bank Nagari Cabang Lubuk Gadang adalah sebgai berikut :

a. Penjadwalan kembali

Kebijaksaan yang diambil oleh pihak bank dalam hal ini memperpanjang kredit, memperpanjang waktu angsuran dan penurunan jumlah yang harus diangsur oleh debitur sehingga denga sedirinya mengakibatkan perpanjangan waktu kredit.

b. Persyaratan ulang

Menerapkan keringanan kredit yang digunakan dalam hal ini adalah perubahan sebagian atau perubahan syarat-syarat kredit antara lain: kapitalisasi bunga, penundaan pembayaran bunga, penurunan suku bunga, penkonversian kredit jangka pendek menjadi kredit jangka panjang dengan persyaratan kredit yang lebih ringan.

c. Penataan ulang

Jika kesulitan nasabah oleh faktor modal tindakan penyelamatan yang dilakukan adalah dengan meninjau kembali situasi dan kondisi permodalan.

d. Kombinasi

Tindakan penyelamtan kredit dapat juga dilakukan dengan kombinasi tindakantindakan diatas.

\section{Tabel 1}

Kredit Usaha Rakyat Dan Kredit Bermasalah

Tahun 2011-2014

\begin{tabular}{|l|l|l|}
\hline Tahun & $\begin{array}{l}\text { Total Kredit yang diberikan } \\
(\mathrm{Rp})\end{array}$ & $\begin{array}{l}\text { Kredit } \\
(\mathrm{Rp})\end{array}$ \\
\hline 2011 & 510.000 .000 & 0 \\
\hline 2012 & 2.094 .000 .000 & 0 \\
\hline 2013 & 2.622 .000 .000 & 63.500 .000 \\
\hline 2014 & 3.701 .000 .000 & 134.900 .000 \\
\hline
\end{tabular}

Sumber : Bank Nagari Cabang Lubuk Gadang.

Dari tabel 3.1 dapat diketahui dalam kegiatan pemberian kredit usaha rakyat tidak selalu berjalan lancar karena adanya kredit bermasalah, yang paling signifikan terjadi pada tahun 2014, kredit bermasalah pengalami peningkatan dari tahun 2013 menjadi Rp.67.400.000 karena diakibatkan adanya krisis keuangan secara global pada tahun tersebut yang berimbas pada penurunan kemampuan nasabah debitur dalam membayar hutangnya. 


\section{KESIMPULAN}

Berdasarkan penelitian dan pembahasan mengenai prosedur pelaksanaan Kredit Usaha Rakyat (KUR) pada Bank Nagari Cabang Lubuk Gadang maka dapat ditarik kesimpulan sebagai berikut:

1. Proses pemberian KUR di Bank Nagari Cabang Lubuk Gadang dilakukan dengan beberapa tahap yaitu: tahap permohonan kredit, tahap peninjauan kredit, tahap pemeriksaan (anilisis kredit), tahap pemberian keputusan, serta tahap pencairan kredit.

2. Para calon debitur yang ingin mendapatkan fasilitas kredit terlebih dahulu mengajukan permohonan tertulis serta melengkapi persyaratan yang telah ditentukan pihak bank yaitu: foto copy kartu identitas yang masih berlaku (KTP/SIM), foto debitur (suami/istri), foto copy kepemilikan agunan (STNK dan BPKB), foto copy perizinan usaha sesuai ketentuan yang berlaku.

3. Agar setiap pemberian kredit kepada debitur dapat berjalan sesuai dengan ketentuan perjanjian kredit maka perlu diberlakukan pengendalian kredit baik itu pada debitur ataupun dalam stuktur organisasi perusahaan, maka sangat diperlukan alat-alat dan fungsi manajemen perusahaan yang lengkap yaitu perlu dirancngnya program yang tepat dalam hal pengendalian kredit bermasalah.

\section{DAFTAR PUSTAKA}

Abdurrachman A, (1991). Enkslikodia Ekonomi Keuangan Perdagangan. Jakarta: Yagrat.

Alanshari, F., \& Marlius, D. (2018). Prosedur Pemberian Kredit KPR Pada PT. Bank Tabungan Negara (Persero) TBK Cabang Pembantu Bukittinggi. https://doi.org/10.31227/osf.io/rsfhc

Amelia, L., \& Marlius, D. (2018). Pengendalian Kredit Dalam Upaya Menciptakan Bank Yang Sehat Pada PT. Bank Pembangunan Daerah Sumatera Barat Cabang Utama Padang. https://doi.org/10.31227/osf.io/kpc64

Departemen Pendidikan Nasional, Kamus Besar Bahasa Indonesia. Balai Pustaka. 1991.

Hermansyah, (2008). Hukum Perbankan Nasional Indonesia. Jakarta: Prenada Media. Intruksi Presiden Nomor 5 tahun 2008 tentang Fokus Program Ekonomi tahun 2008-2009

Kasmir. 2010. Bank dan Lembaga Keuangan Lainnya. Jakarta: Raja Grafindo Persada.

Kasmir. 2012. "Bank dan Lembaga Keuangan Lainnya”. PT. Rajagrafindo Persada. Jakarta.

Thomas Suyatno, dkk, (2007). Dasar-dasar Perkreditan. Jakarta: PT. Gramedia

Pustaka Utama. 
Muhammad Djumahana, (1996). Hukum Perbankan di Indonesia, Bandung: PT. Aditya Bhakti.

Munir Fuady, (2001). Hukum Perkreditan Kontenporer, Cetakan Kesatu, PT. Citra Aditya Bakti, Bandung.

Poerwadarminta, W.J.S 1990. Kamus Umum Bahasa Indonesia. Jakarta: Balai Pustaka.

Republik Indonesia. 1998. Undang-Undang Nomor 10 Tahun 1998 Tentang Perubahan Undang-Undang Nomor 7 Tahun 1992 Tentang Perbankan. Jakarta. 